\title{
Effects of Use Myrtle Oil (Myrtus commonis) on Body Weight and Some Blood Parameters in Local Male Rabbits
}

Hawraa Hamed Naji
Oday Suliaman Khudhair Firas Hussain Kadhim Albawi

\author{
Amer Jebur Opyas
}

\section{AL-Qassim green University, College of Veterinary Medicine}

\author{
hawraa.alsulany83@gmail.com \\ Dr.Amer-42-vet@yahoo.com
}

\author{
Odayaljubre@gmail.com \\ Firas74kadhim@Yahoo.com.
}

\begin{tabular}{l}
\hline ARTICLE INFO \\
\hline Submission date: $22 / 7 / 2018$ \\
Acceptance date: $30 / 9 / 2018$ \\
Publication date: $10 / 3 / 2019$ \\
\hline
\end{tabular}

\begin{abstract}
Study was conducted to evaluate the effect of (Myrtus communis) oil on the weight of body and some Hematological in the local male rabbits. (15) rabbits average (1078-1088) gram were divided to (3) groups, every group (5) rabbits, group (1) the control gives only (0.2) ml tap water orally, while group (2), (3) gives Myrtle oil (0.1) $\mathrm{ml} / \mathrm{kg},(0.2) \mathrm{ml} / \mathrm{kg}$ respectively orally for (2) month. We conducted that the administration of Myrtle oil produces a significance decrease $(\mathrm{P}<0.01)$ at $0.1 \mathrm{ml} / \mathrm{Kg} . \mathrm{B} . \mathrm{W}$. and $0.2 \mathrm{ml} / \mathrm{Kg}$.B.W in the body weight, there is a significance increase $(\mathrm{P}<0.05)$ at $0.1 \mathrm{ml} / \mathrm{Kg} . \mathrm{B}$.W. in values of RBCs, WBCs, $\mathrm{Hb}$ and PCV, there is a significance decrease $(\mathrm{P}<0.05)$ at $0.2 \mathrm{ml} / \mathrm{Kg}$. B.W. in values of RBCs,WBCs, $\mathrm{Hb}$ and PCV. While there is no significance $(\mathrm{P}<0.05)$ in the value of PLT. We concluded that, the administration of Myrtle oil in low dose produces good effects whereas administration of it in high dose produce bad effects in the body functions.
\end{abstract}

Key words: Myrtle oil, Body weight, Hematology, Local male rabbits.

\section{Introduction}

The oil of Myrtle (Myrtus communis) comes from Myrtus the Greek name from Myrtle and communis means common plant growing in groups. Myrtus communis (FamilyMyrtaceae) is an aromatic evergreen perennial shrub or small plant, 1.8-2.4 $\mathrm{m}$ in height with small foliage and deep fissured bark. It's native to North Africa, Southern Europe and West Asia. It's widespread in the in the Mediterranean region, it's found in most green gardens for it's fragrant flowers. The leaves of Myrtle plant have a dark green are glossy, glabrous, flowers of myrtle plant axillary white on slender peduncles, medium sized about $2 \mathrm{~cm}$ in diam. They give off a sweet fragrant smell. The berries are pea-sized ovoidellipsoid or orbicular, blue-black or white with hard kidney shaped seeds, They are of varying sizes $0.7-1.2 \mathrm{~cm} \mathrm{[1],[2],[3].} \mathrm{Oil} \mathrm{of} \mathrm{myrtle} \mathrm{is} \mathrm{the} \mathrm{essential} \mathrm{oil} \mathrm{of} \mathrm{M.communis,}$ 
which is produce from extracted of there a green leaves, branches, fruits and flowers through steam distillation [3],[4].

Phytochemical constituents of Myrtle plant contain many substances like fibers, sugars and antioxidants and many biologically active compounds phenolic compounds, flavonoids and anthocyanins [5],[6]. seeds yield 12-15\% of a fatty oil (fixed oil) consisting of glycerides of linoleic, oleic, linolenic, palmitic and lauric acid [7],[8]. Many studies on fatty acid analysis of Myrtle fruits showed that it contains 14 fatty acids, oleic acid being the dominate fatty acid (67-70\%) fallowed by palmatic acid (10-24\%) and stric acid (8-19 \%) [9]. Medicinal and other uses to Myrtle oil traditionally use as disinfectant, antiseptic drug and hypoglycaemic agent, anti-inflammation, anti-emetic, diuretic, and cardiolonic , diarrhea, dysentery, internal ulceration and rheumatism, foot ulcers, haemorrhges, bronchitis , malaena, rhinitis, conjunctivitis [10],[11],[12],[13],[6]. Myrtle oil uses in many food industry like flavoring meat and sauces and in the cosmetic industry and hair tonic [14],[15],[16]. Ripe fruits of myrtle were used as food integrators because of their high vitamin contents [17].The cold and hot water extracts have antibacterial activity against all Gram positive and negative bacteria and pathogenic Candidia albicans except Klebsiella pneumoniae [18].

\section{Materials and Methods}

The study was conducted in the period from April 2018 - June 2018 in veterinary public health department of Veterinary Medicine of AL-Qassim Green University. The number of laboratory animals used in the experiment are (15) healthy male rabbits at (1078-1088) gram weight obtained from the local markets, the animals were divided randomly into three groups, each group consisting of (5) rabbits, were kept for one week as acclimatization period before the start of the experiment.The experiment involved the use of two concentrations spread over four replications were used the following materials:

- Myrtle plant oil (Myrtus communis) natural concentration 100\% factory in Imad Company for Vegetable Oils / Mosul.

- The dosage rabbits orally by special modified syringe for this purpose.

\section{Experimental Design}

After the acclimatization period, rabbits were divided into three equal groups, each of five rabbits. First group (G1); was control administered tap water daily. The second group (G2) and Third group (G3); was administered Myrtle oil (0.1, $0.2 \mathrm{ml} / \mathrm{kg} \mathrm{B.W}$ ) respectively.

All treated animals were administrated orally for period of tow months, by using modified stomach tube, has rabbit feed on concentrated feed (pellets) and were given plain water, it has been isolated animals room temperature at (19-23 $C^{\circ}$ ), and the humidity (45 -55\%), was washing and sterilization of the room once a week. Body weight was taken in the started and in the end of study. At the end of the experimental period, rabbits were fasted for) 10( hrs. And anesthetized using diethyl ether and blood samples were collected from heart puncture in heparinized tubes to blood picture, collecting blood use anticoagulant tubes to blood parameters total RBCs, WBCs, PLT count, percentage of PCV and concentration of $\mathrm{Hb}$. 


\section{Statistical analysis}

The statistical analysis was carried out for data on this experience according to Complete Randomized Design [19]. In order to determine the impact of different levels of Myrtle oil in the oral dosage on the study traits of local male rabbits. Random experimental error of the unit test, which is distributed normal and independent with an average of zone and the variance is equal to $\mathrm{O}^{2} \mathrm{e}$. It was the comparison between the averages by using the Duncan test [20]. At tow way of level of probability $1 \%$ and $5 \%$ to test the significant differences between the averages of traits and applying the statistical program [21].

\section{Results}

Body weight effect of Myrtle oil : The result of body weight (Kg/ B.w) is shown in the Table (1).results showed there was significant decrease $(\mathrm{P}<0.01)$ between $\mathrm{G} 2$ witch body weight was $(1.17 \pm 0.00)$ and $\mathrm{G} 3$ witch was $(1.16 \pm 0.01)$ whine compared with G1 witch body weight was $(1.32 \pm 0.01)$.

Table (1) : Myrtle oil effect on initial and final body weight (mean $\pm \mathrm{SE}$ ).

\begin{tabular}{|c|c|c|c|}
\hline $\begin{array}{l}\text { Groups } \\
\text { Parameter }\end{array}$ & $\begin{array}{c}\text { G1 } \\
\text { Control }\end{array}$ & $\begin{array}{c}\text { G2 } \\
\left(\begin{array}{c}\text { o.1 ml/Kg.B.W }) \\
\text { orally }\end{array}\right.\end{array}$ & $\begin{array}{c}\text { G3 } \\
(0.2 \mathrm{ml} / \mathrm{Kg} . \mathrm{B} . \mathrm{W}) \\
\text { Orally }\end{array}$ \\
\hline Initial body weight & $1.27 \pm 0.01 \mathrm{~A}$ & $1.26 \pm 0.00 \mathrm{~A}$ & $1.28 \pm 0.01 \mathrm{~A}$ \\
\hline Final body weight & $1.32 \pm 0.01 \mathrm{~A}$ & $1.17 \pm 0.02 B$ & $1.16 \pm 0.01 \mathrm{~B}$ \\
\hline
\end{tabular}

Different letters means significant $(P<0.01)$ between groups in the same row.

Haematological effect of Myrtle oil: The result of RBCs count $\left(10^{12}\right.$ cell/l) is shown in Table (2). The results showed there were significant increase $(\mathrm{P}<0.05)$ of $\mathrm{G} 2$ which RBCs count was $(6.08 \pm 0.29)$ whine compared with $\mathrm{G} 1$, which was $(5.49 \pm 0.18)$ and there is a significant decrease $(\mathrm{P}<0.05)$ between G3 witch RBCs count was $(5.04 \pm 0.23)$ when compared with G1. And there is a significant decrease $(\mathrm{P}<0.05)$ between G3 which RBCs count compared with G2. The data of WBCs count $\left(10^{9} \mathrm{cll} / \mathrm{l}\right)$ are shown in Table (2). The results showed significant increase $(\mathrm{P}<0.05)$ of $\mathrm{G} 2$ which WBCs count was $(9.06 \pm 0.46)$ when compared with G1witch was $(7.90 \pm 0.76)$ and there is significant decrease between

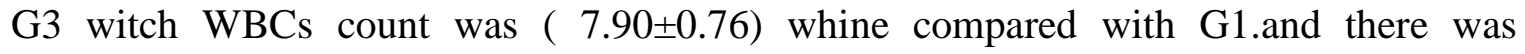
significant decrease $(\mathrm{P}<0.05)$ between $\mathrm{G} 3$ witch WBCs count compared with $\mathrm{G} 2$. The result of $\mathrm{Hb}(\mathrm{mg} / \mathrm{dl})$ is shown in Table (2).The result showed there was significant increase $(\mathrm{P}<0.05)$ of $\mathrm{G} 2$ which the $\mathrm{Hb}$ value was $(14.32 \pm 0.67)$ whine compared with $\mathrm{G} 1$ which was $(13.58 \pm 0.18)$. and there is significant decrease $(\mathrm{P}<0.05)$ in $\mathrm{Hb}$ value of $\mathrm{G} 3$ which was $(12.50 \pm 0.46)$ whine compared with $\mathrm{G} 1$. And there is significant decrease $(\mathrm{P}<$ $0.05)$ between G3 witch $\mathrm{Hb}$ value compared with G2.The data of PCV (\%) are listed in Table (2). Showed significant increase $(\mathrm{P}<0.05)$ of G2 which PCV $(\%)$ was $(40.54 \pm 1.58)$ when compared with G1which was $(38.80 \pm 0.53)$ and there is significant decrease $(\mathrm{P}<$ $0.05)$ between G3 which PCV (\%) was $(35.04 \pm 1.78)$ when compared with G1. And there is significant decrease $(\mathrm{P}<0.05)$ between G3 which PCV $(\%)$ compared with G2.The 
result of PLT count $\left(10^{3} / \mathrm{mm}^{3)}\right.$ is shown in Table (2). The results showed there were no significant differences $(\mathrm{P}<0.01)$ between treatment group compared with control group.

Table (2) : Myrtle oil effect on Haematological parameters $\mathrm{RBC}\left(10^{12}\right.$ cell/l),WBC $\left(10^{9}\right.$ cell $\left./ \mathrm{l}\right), \mathrm{Hb}(\mathrm{g} / \mathrm{dl}), \operatorname{PCV}(\%)$ and PLT $\left(10^{3} / \mathrm{mm}^{3}\right)($ mean $\pm \mathrm{SE})$.

\begin{tabular}{|l|c|c|c|}
\hline & $\begin{array}{c}\text { G1 } \\
\text { Control } \\
\text { Parameter }\end{array}$ & $\begin{array}{c}\text { G2 } \\
\text { ml/Kg.B.W }) \\
\text { orally }\end{array}$ & $\begin{array}{c}\text { G3 } \\
(\mathbf{0 . 2} \text { ml/Kg.B.W }) \\
\text { Orally }\end{array}$ \\
\hline RBCs & $5.49 \pm 0.18 \mathrm{AB}$ & $6.08 \pm 0.29 \mathrm{~A}$ & $5.04 \pm 0.23 \mathrm{~B}$ \\
\hline WBCs & $7.90 \pm 0.76 \mathrm{AB}$ & $9.06 \pm 0.46 \mathrm{~A}$ & $6.76 \pm 0.67 \mathrm{~B}$ \\
\hline Hb & $13.58 \pm 0.18 \mathrm{AB}$ & $14.32 \pm 0.67 \mathrm{~A}$ & $12.50 \pm 0.46 \mathrm{~B}$ \\
\hline PCV & $38.80 \pm 0.53 \mathrm{AB}$ & $40.54 \pm 1.58 \mathrm{~A}$ & $35.04 \pm 1.78 \mathrm{~B}$ \\
\hline PLT & $317.20 \pm 30.94 \mathrm{~A}$ & $372.20 \pm 39.27 \mathrm{~A}$ & $280.40 \pm 39.54 \mathrm{~A}$ \\
\hline
\end{tabular}

Different letters means significant $(\mathrm{P}<0.05)$ between groups in the same row.

\section{Discussion}

The observed of body weight,which recorded in table (1) show there was a significant decrease in body weight between G2 and G3 compared with G1, at $(0.1 \mathrm{ml}$ and 0.2 $\mathrm{ml} / \mathrm{Kg} . \mathrm{B} . \mathrm{W}$ ) respectively, may be due to present the Poly phenol compounds in the myrtle oil and this compounds led to increase the metabolism in the body, specially increase of catabolism of fat in the body and this led to loss of body weight [22].

Use of the herbal plants lead to increase of blood parameters (RBCs, WBCs, Hb,PCV) may be according in the chemical structure include protein, fat, carbohydrate, iron, calcium, Vitamin A, thiamine and riboflavine. This most of blood factors have direct effects on blood production (Haemopoiesis) in the bone marrow [23].

The observed of increase of Erythrocytes count which recorded in table (2) show there were significant increase between $\mathrm{G} 2$ compared with $\mathrm{G} 1$ at $(0.1 \mathrm{mg} / \mathrm{Kg}$. BW) may be due to present of bioactive compounds like (polyphenols, polyunsaturated fatty acids, tannins and presence of vitamins [24]. lead to increase of hemopoiesis in the bone marrow and this result agree with [25]. Which recorded there was positive effect on total count of Erythrocytes when given $2000 \mathrm{ppm}$ lead together with Pomegrate juce $(\mathrm{Pj})$ in rats at dose $30 \mu 1,60 \mu 1$ (Pj; equivalent to $1050 \mu \mathrm{mol}, 2100 \mu \mathrm{mol}$ total polyphenols) respectively led to increase of Erythrocytes total count. The observed of increase leukocytes count in table (2) which recorded in $\mathrm{G} 2$ at dose $(0.1 \mathrm{mg} / \mathrm{Kg}$.BW) may be due to supporting of immune system [26]. Myrtle oil contain many of bioactive compounds phenolic compounds, flavonoids and anthocyanins [5],[6].Lead to an increase of leukocytes in the body and this result agreement with [25]. Which recorded there was positive effect on total count of Leukocytes when given $2000 \mathrm{ppm}$ lead together with Pomegrate juce $(\mathrm{Pj})$ in rats at dose 
$30 \mu 1,60 \mu \mathrm{l}$ (Pj; equivalent to $1050 \mu \mathrm{mol}, 2100 \mu \mathrm{mol}$ total polyphenols) respectively led to increase of Leukocytes total count. The observed of increase $\mathrm{Hb}$ value which recorded in table (2) show there were significant increase between G2 compared with G1 at $(0.1 \mathrm{mg} / \mathrm{Kg} . \mathrm{BW})$ may be due to role of bioactive compound like (polyphenols, polyunsaturated fatty acids, tannins and presence of vitamins [24]. Lead to increase of hemopoiesis in the bone marrow and this result agrees with [25]. Which recorded there was a positive effect on $\mathrm{Hb}$ value when given $2000 \mathrm{ppm}$ lead together with Pomegrate juce $(\mathrm{Pj})$ in rats at dose $30 \mu \mathrm{l}, 60 \mu \mathrm{l}(\mathrm{Pj}$;equivalent to $1050 \mu \mathrm{mol}, 2100 \mu$ mol total polyphenols) respectively led to increase of $\mathrm{Hb}$ value. The observed of increase PCV\% in table (2) which recorded in $\mathrm{G} 2$ at dose $(0.1 \mathrm{mg} / \mathrm{Kg}$. BW $)$ may be due to bioactive compounds which lead to increase of hemopoiesis in bone marrow[5][6].

This result agreement with[25]. showed increase of PCV percentage when given 2000 ppm lead together with Pomegrate juce $(\mathrm{Pj})$ in rats at dose $30 \mu 1,60 \mu \mathrm{l}(\mathrm{Pj}$; equivalent to $1050 \mu \mathrm{mol}, 2100 \mu \mathrm{mol}$ total polyphenols) respectively. The observed of PLT count which recorded in table (2) show there were no significant differences between G2 and G3 compared with G1.

\section{Conclusions}

The administration of myrtle oil in low dose produces good effects whereas administration of it in high dose produces bad effects on body functions.

\section{CONFLICT OF INTERESTS.}

There are non-conflicts of interest.

\section{References}

[1] P. Mouterde, “Nouvelle flone du liban et dela syrie, tom II, Beyrouth dar el Machreg,, P563, Pp. 1-725,1983.

[2] Medicinal Plant of India, “Indian Council of Medical research,, New Delhi. Vol. II. Pp. 310-311.1987.

[3] K.M. Nadkarni, “Indian Materia Medica,, 3rd Edn, Popular Prakashan Pvt. Ltd., Bombay. Vol. 1. P.838,1989.

[4] M. Stuart, The Encyclopedia of Herbs and Herbalism,, 3rd Edn. Pp. 52-136,1994.

[5] A. Dogan, “Investigations Myrtus commonis L., plant's volatile oil yield, their physical-chemical properties and their compositions, Turkish: Ankara University. Agricultural Faculty Press. P. 678,1978.

[6] N. Hayder, A. Abdelwaheda, S. Kilania, R. Ben-Ammar, A. Mahmoud, and K. Ghedirb, "Anti-genotoxic and free-radical scavenging activities of extracts from (Tunisian) Myrtus communis,, Mutat Res, 564: 89-95,2004.

[7] The Wealth of India. ، A Dictionary of Indian Raw Materials and Industrial ProductsRaw Materials Series, Publications and Information Directorate, Council of Scientific \& Industrial Research, New Delhi, India. Vol. VI. Pp. 482-483,1962

[8] R.P. Rastogi, and B.N. Mehrotra, “Compendium of Indian Medicinal Plants (19701979),, Central Drug Research Institute Lucknow,Vol.2, Publications and Information Directorate, CSIR,New Delhi.p.478, 1991.

[9] S. Serce, S. Ercisli, M. Sengul, K. Gunduz, and E. Orhan, "Antioxidant activities and fatty acid composition of wild grown myrtle (Myrtus communis L.) fruits,, Phcog. Mag.. 6: Pp. 9-12,2010.

[10] M.A. Hakeem, ‘Bustanul Mufradat, Idara Tarraqui Urdu Publications,, Lucknow. P.278, 1895 . 
[11] M.N.Ghani, A. Khazainul, M. Sheikh, and S. Bashir, “Pubication Urdu Bazar,, Lahore, Pakistan. Pp. 47-48,1920.

[12] M. Kabiruddin, M.B. Sheikh, and Sons. “Makhazn-ul-Mufradat,, Lahore, Pakistan. Pp. 47-48,1951.

[13] M.S. Elfellah, M.S. Akhter, and M.T. Khan, “Antihyperglycaemic effect of an extract of Myrtus communis in streptozotocin-induced diabetes in mice,, J. Ethnopharmacol, 11: 275-281,1984.

[14] M. Ali and S.H. Ansari, "Herbal drugs used as hair tonic, In: National seminar on the use of Traditional Medicinal plants in skincare,, CIMAP, Lucknow, November 2526,P20.1994.

[15] J. Chalchat, R.P. Garry, and A. Michet, “Essential oils of myrtle of the Mediterranean littoral,, j. Essent. Oil Res, 10, 613-617,1998.

[16] Z.I. Baitar, "Aljameul Mufradat Al-advia-wa- al-Aghzia,, Vol. 1, Translated by CCRUM, New Delhi, Pp. 42-47, 1999.

[17] G.Flaminia, P.Cionia, I.Morellia, S. Maccionib, and Baldini, “Phytochemical typologies in some population of Myrtus communis L. on Caprione Promonotory,, East Liguria, Italy, Food Chem. 85: 599-604,2004.

[18] A. Zinab, “Bio effect of some Syrian Myrtus communis L. Leaves extracts in the growth of some pathogenic Microorganisms,, Journal of Basic Sciences Damascus University. Vol. 28: Pp. 51-69,2012.

[19] K.M. AL-Rawi, and M.K, “Design and Analysis of Agriculture Experiments. Dar AL-Kutob press for printing and publishing,, Mosul University, 2000.

[20] C.B. Duncan, “Multiple range and multiple,, F. tests. Biometric. 11: 1-12,1955.

[21] SAS. Statistical Analysis System. SAS institute Inc. Release, Virgin 7.12 Tsozo, North Carolina state University of Cary, NC, U.S.A.2010.

[22] M.R. Tia, A. Sanjiv, and C.M. Kevin,“Anti obesity effects of green tea catechins,, a Mechanistic review, the Journal of Nutritional Biochemistry, Issue 1, Folder 22, Pp. 1-7 Edited,2011.

[23] W. F.Ganong, "A review of medical physiology,, P.g. 496. Appleton and Large, 1997.

[24] D.M.Bagch, J.S. Bagchi, D.S. Stohs, K.C.S. Ray, and G.H. Preuss, “Cellular Protection with Proanthocyanidins Derived from Grape seed, Ann. N. Y.Acad.Sci. New York Academy of Sciences., 957: 260-270,2002.

[25] D.S. Aksu, M. Didin, and F. Kayikei, "The protactive role of Polyphinols on blood cells in Rats exposed to Lead,, Revista Romana de Midicined de laboratory Vol. 20, Nr.3/4.Pp. 233-243,2012.

[26] E. Nancy, "In The Laboratory Mouse,, Edited by Hans JH, Gilian B. Peter P. Elsevier. Academic Press. UK, Pp. 271- 285,2004. 


\section{الخلاصة}

اجريت هذه الدراسة لمعرفة تأثير زيت نبات الياس في وزن الجسم وبعض المعاير الدمية لذكور الأرانب المحلية. استعمل في الدراسة (15) ارنب (1078 - 1088) غرام وقسمت إلى ثلاث مجاميع, كل مجموعة تضم (5) أرانب, وكانت المجموعة الأولى السيطرة

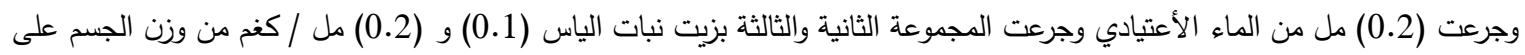

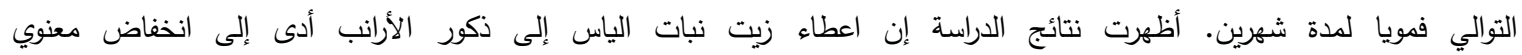

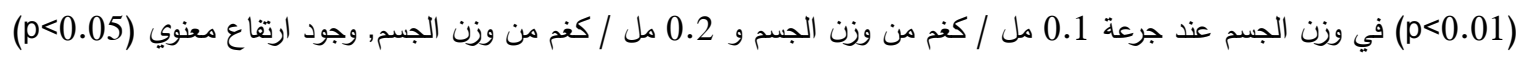

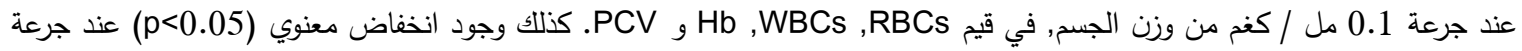

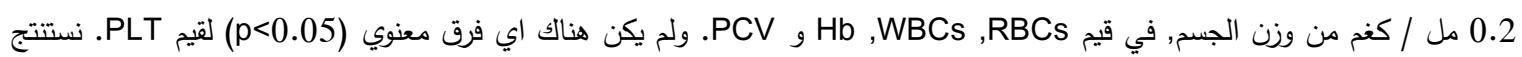
من ذلك إن اعطاء زيت الياس عند الجرع الصغيرة ينتج عنة تأثيرات جيدة بينما اعطاء زيت الياس بجرعات كبيرة ينتج عنة تأثيرات غير لفئ جيدة في وظائف الجسم. 